\title{
Exporting against Risk? Theory and Evidence from Public Export Insurance Schemes in OECD Countries
}

\author{
Ernst Baltensperger • Nils Herger
}

Published online: 29 January 2008

(C) Springer Science + Business Media, LLC 2007

\begin{abstract}
This paper endeavours to find out in how far public export insurance schemes foster international trade. Thereto, a gravity equation is derived, which accounts for the risk of financial losses in case firms contract defaulting foreign buyers. Empirical results suggest that OECD countries issuing trade credits with generous state-guarantees did not, during the 1999 to 2005 period, witness more exports towards politically and commercially more unstable lowincome countries. Rather, publicly indemnified trade finance has promoted exports, to a modest degree, towards high and middle-income countries, where financial intermediaries and markets provide viable alternatives to hedge against payment risks.
\end{abstract}

Keywords Export credit insurance - Export promotion • Default risk • Gravity equation

\section{JEL Classification F13}

As soon as the cost of producing and delivering goods is not counterbalanced by instantaneous payments, the desire for trade finance arises. Indeed, debt instruments such as trade credits permit firms to finance the delays that arise in successive transactions without having to surrender internal funds. Meanwhile, such a temporary detachment between pecuniary and goodstransactions exposes firms to the risk of default. Incomplete information as

E. Baltensperger · N. Herger $(\bowtie)$

Department of Economics, University of Berne,

Schanzeneckstrasse 1, Postfach 8573, 3001 Berne, Switzerland

e-mail: nils.herger@vwi.unibe.ch

E. Baltensperger

e-mail: ernst.baltensperger@vwi.unibe.ch 
regards the creditworthiness of foreign buyers, the menace of a political or financial crisis, or the hazards involved in enforcing international contracts, exacerbate the risk to be confronted with incomplete transactions in crossborder trade finance.

To mitigate against such risk, banks and insurance companies offer a wide range of policies indemnifying exporters against the losses from defaulted trade credits that mature within 12 months. Conversely, owing to a combination of aggravated levels of incomplete information and the menace of risk contagion across entire countries or even regions, the private export insurance industry is arguably reluctant to cover long-term and political risks. ${ }^{1}$ This applies in particular when trade credits involve a sovereign buyer in a developing country. Nevertheless, to provide trade credit insurance for firms wishing to export towards countries suffering from nonmarketable levels of default risk, most OECD countries maintain export credit agencies (ECAs) - either in the form of ministerial departments, or publicly owned or supported insurance companies-commissioned to issue trade credits with a state-guarantee. Export promotion and the desire to open up risky marketswhich are primarily located in developing countries-for international trade have, among others, been put forward as rationales for public intervention in the export insurance industry. Yet, the public promise to bail out financially unsound insurance portfolios may put ECAs in a position to cover export credits at premiums deemed unprofitable by the private industry. The lure of inconspicuous export subsidisation has lead to international agreements such the OECD's "Arrangement on Officially Supported Export Credits" (hereafter 'Knaepen Package') to prevent the issuance of state-guarantees on trade credits distorting competition in the export insurance industry. ${ }^{2}$

According to the Berne Union (2006, p.169), an international organisation representing the credit and investment insurance industry, in 2004, public and private export insurance companies underwrote almost 800 billion US\$ worth of new trade credits, collected around 5 billion US $\$$ in premiums, and disbursed claims of around 3.4 billion US\$. Thereby, almost $90 \%$ of business was issued by private banks and insurance companies for the short-term, e.g. on export transactions clearing within 12 months (Stephens 1998, p. 5). Conversely, despite underwriting less than $10 \%$ of the grand total of policies, ECAs backed by a state-guarantee held a far larger market share in medium and long-term export credit insurance (Fingerand and Schuknecht 1999) that accounted for around $60 \%$ of collected premiums and $80 \%$ of the disbursed claims.

\footnotetext{
${ }^{1}$ See Fingerand and Schuknecht (1999) and Alsem et al. (2003) for an overview of the structure of the export insurance industry.

${ }^{2}$ Other trade regulators have adopted rules on the legal conduct of public export insurance schemes. The WTO's "Agreement on Subsidies and Countervailing Measures" outlaws bailing out unprofitable export insurance schemes with public funds as illegitimate industry subsidisation. By means of the Council Directive 98/29/EC, the European Union attempts to harmonise the rules underlying the public provision of medium and long-term export credit insurance across member countries.
} 
In spite of their implications for the international trading system, ECAs have received relatively scant attention in the economic literature. Notable exceptions include Dewit (2001), who adopts a political economy perspective to suggest that ECAs installed to mitigate against nonmarketable payment risks may instead pursue development aid policies or respond to lobbying efforts by industries seeking subsidised insurance. Thereby, risky export markets exacerbate the caveats invoked against strategic trade policies insofar as the degree to which firms avert the risk that foreign buyers default on their financial obligations, affects the design of the welfare-improving export insurance scheme. Therefore, successful export promotion in the form of issuing trade credits with a state-guarantee necessitates information in excess of the amount already deemed unobtainable in case of instantaneous financial transactions. ${ }^{3}$ Arguably, vested interests provide more compelling theoretical rationales to explain why public ownership and financial guarantees are upheld within the export insurance industry. Other papers include Abraham and Dewit (2000), who conclude for the case of the Belgian export insurance scheme, that subsidised insurance tends to be offered primarily to firms trading with former colonies. Finally, Dewit (2002) suggests that public export insurance schemes distort the incentive of multinational firms to invest in local plant capacity in favour of shipping commodities to foreign markets.

Against this background, the present paper endeavours to estimate some of the empirical implications of the economic theories on the interrelationship between the public provision of export insurance and international trade. In particular, based on a gravity equation augmented with the contingency of default on international payments, the principal contribution lies in estimating the empirical extent to which various insurance policy parameters such as payment risks, insurance coverage, premium rates, or asserted claims end up affecting a country's exports. To this end, a new panel has been assembled containing data on the volume of export insurance officially supported by OECD countries between 1999 and 2005.

Results suggest that in spite of public export insurance schemes, the risk of foreign default continues to impede international trade in countries suffering from aggravated levels of political and commercial instability. Furthermore, for the 1999 to 2005 period, there is evidence that issuing trade credits with generous state-guarantees has, to a modest degree, promoted exports to high and medium-income countries, but has been ineffective in opening up lowincome countries for more international trade.

The remainder is organised as follows. Section 1 derives a gravity equation to extract the hypothesis on the relationship between export flows and the public provision of export insurance policies. Section 2 confronts the hypothesis with the data by consecutively introducing the data set, the empirical strategy, and discussing the results. The final section summarises and concludes.

\footnotetext{
${ }^{3}$ Based on a slightly different model where export credit is offered at below market interest rates rather than covered by subsidised insurance, Carmichael (1987) reaches a similar conclusion.
} 


\section{A gravity equation with risky exports}

Attributing cross-country flows in goods to differences in economic mass (size) as well as cultural and geographical proximity remains the canonical framework for conducting empirical analysis in international trade. However, it was not until Anderson and Wincoop (2003) that the gravity relationship was firmly integrated into a general equilibrium framework. Drawing on Abraham and Dewit (2000) as well as Dewit (2001), this section adds to the gravity equation the contingency that exporting firms are confronted with the risk of default against which insurance from officially owned and supported export credit agencies (ECAs) can be taken out. Linking the value of exports with export insurance parameters such as payment risks, premium rates, or prospective indemnities allows to extract theoretically underpinned priors, on the basis of which econometric equations will be specified to measure how ECAs impinge on international trade.

In each importing country $j$, the demand for product brands manufactured by the representative firm of exporting country $i$ decreases in price $p_{i j}$, relative to the consumer price index $P_{j}$, and increases in economic size in terms of national income $Y_{j}$. Then, nominally valued imports for commodities are given by $x_{i j}=\left(p_{i j} / P_{j}\right)^{1-\sigma} Y_{j}$ with $\sigma>1$ denoting the constant elasticity of substitution. ${ }^{4}$

As noted at the outset, insofar as payments do not occur on a frictionless basis, exporters are confronted with the risk of contracting defaulting buyers. To promote exports in risky markets where private insurance is off-cover, ECAs underwrite insurance on behalf of the state, reimbursing an amount $\gamma_{i j}$ in case of default against collecting a premium $r_{i j}$ per insured currency unit. Residents in country $j$ declare insolvency with exogenous probability $\lambda_{j}$. Letting $R\left(q_{i j}\right)$ denote revenue, the expected profit accruing to exporting $q_{i j}$ to market $j$ is

$$
E\left[\pi_{j}\right]=\left(1-\lambda_{j}\right) R\left(q_{i j}\right)+\left(\lambda_{j} \gamma_{i j}-r_{i j}\right) R\left(q_{i j}\right)-c_{i} \tau_{i j} q_{i j}
$$

where the factor $\tau_{i j} \geq 1$ reflects natural and artificial trade barriers that add up to marginal production $\operatorname{cost} c_{i}$. Insurance policies that charge actuarially fair premiums and offer comprehensive coverage, that is $r_{j}=\lambda_{j}$ and $\gamma_{i j}=1$, permit full insulation against payment risks since then $E\left[\pi_{j}\right]=\pi_{i j}=\left(1-\lambda_{j}\right) R\left(q_{i j}\right)-$ $\tau_{i j} c_{i} q_{i j}$. Owing to the implicit assumption of risk neutrality, buying no insurance $\left(\gamma_{i j}=0, r_{i j}=0\right)$ would leave firms with a profit level they deem equivalent. However, due to asymmetric information about the probability of default or the frictions involved in international contract enforcement, export insurance markets are arguably incomplete, in particular when it comes to obtaining coverage against the event of political instability. To correct such alleged

\footnotetext{
${ }^{4}$ For further details on this see e.g. Anderson and Van Wincoop (2003, pp. 174-175). 
market failure, firms may want to lobby the public to issue state-guarantees allowing insurance companies to charge premiums that do not accurately reflect the probability of default $\left(r_{j}<\lambda_{j}\right)$. This gives, in turn, rise to the desire to take out maximal insurance coverage $\overline{\gamma_{i j}}$ yielding the highest expected return in the event that an exporter is confronted with default. ${ }^{5}$ Such public schemes mandate, however, subsidies when $s_{i j}\left(\gamma_{i j}, r_{i j}\right)=\lambda_{j} \gamma_{i j}-r_{i j} \geq 0$ with $\frac{\partial s}{\partial \gamma}>0$ and $\frac{\partial s}{\partial r}<0$. To militate against financially unsound insurance portfolios-a practice outlawed as illicit export subsidisation under OECD and WTO regulationsECAs may want to impose coverage ceilings that leave some of the risk with the exporter, e.g. $\bar{\gamma}_{i j}<1$ (see Abraham and Dewit 2000; Dewit 2001). Markets with particularly patchy credit histories may even be put completely off-cover. Furthermore, Henry (1987) as well as Boote and Ross (1998) attribute the fact that many public insurance schemes report profits, despite covering risks considered nonmarketable by private insurers, to overvalued prospects of making recoveries $\rho$ on claims involving, in particular, a sovereign borrower. Anticipating a public bailout may indeed allow to write-off overdue payments issued with a state-guarantee in a less prudent manner. Coverage ceilings and recoveries, thus, enable ECAs to fund an export insurance portfolio where disbursed claims exceed collected premiums without necessarily inflicting losses upon the taxpayer, that is

$$
\pi_{E C A}=\rho_{i j}+r_{i j}-\lambda \bar{\gamma}_{i j}=\rho_{i j}-s\left(\bar{\gamma}_{i j}, r_{i j}\right) \geq 0
$$

Detailing revenues by $R\left(q_{i j}\right)=q_{i j} p_{i j}=p_{i j}\left(q_{i j}\right) p_{i j}$ and introducing Eq. 2 into Eq. 1 implies that expected profits from exporting to country $j$ are given by $E\left[\pi_{j}\right]=\left[1-\lambda_{j}+s\left(\bar{\gamma}_{i j}, r_{i j}\right)\right] p_{i j}\left(q_{i j}\right) q_{i j}-\tau_{i j} c_{i} q_{i j}$. The price

$$
p_{i j}=\frac{c_{i} \tau_{i j}}{(1-1 / \eta)(1-\lambda+s(\bar{\gamma}, r))}
$$

that satisfies profit maximisation increases in trade costs $\left(\tau_{i j}\right)$ and markup $(1 / \eta)$, where $\eta$ denotes the industry elasticity of demand, and decreases in more generous export insurance schemes, on which for the sake of notation, subscripts have been suppressed. Assuming that markets are structured by (Dixit-Stiglitz) monopolistic competition implies that firms face horizontally sloped demand curves, that is $\eta=\infty$, under which positive mark-ups are competed down.

To obtain the gravity relationship, we follow the five steps in Baldwin and Taglioni (2006) that are (1) adding up per variety export demand $x_{i j}$

\footnotetext{
${ }^{5}$ To see this, observe that the second term on the right hand side of Eq. 1 contributes maximally to expected profits in case $\left(r_{j}<\lambda_{j}\right)$ and $\left(\gamma_{i j}=1\right)$. According to Abraham and Dewit (2000) as well as Dewit (2001), exporters exhibiting some degree of risk aversion desire to insure fully even if premiums are actuarially fair.
} 
across the number, $n_{i}$, of brands to obtain the total value of exports, $X_{i j}$, between countries $i$ and $j$ (2) introducing profit maximising prices of Eq. 3 that account in particular for the role of export insurance (3) adding up the total value of exports, $X_{i j}$, across all foreign markets $j$ which yields the identity for national income $Y_{i}$ (4) proxying for market potential by parameterising $\Omega_{j}=\sum_{j}\left[\tau_{i j}^{1-\sigma} \frac{Y_{j}}{P_{j}^{1-\sigma}}\right]$, and (5) solving the identity for national income $Y_{i}$ for $n_{i}$ and substituting back into the total value of exports $X_{i j}$. ${ }^{6}$ This yields the basic gravity relationship

$$
X_{i j}=\frac{Y_{i} Y_{j}}{\Omega_{j} P_{j}^{1-\sigma}}\left[\frac{(1-\lambda+s(\bar{\gamma}, r))}{\tau_{i j}}\right]^{\sigma-1}
$$

insofar as the value of exports, $X_{i j}$, originating in country $i$ and destined for country $j$ (a) increases in joint economic size, $Y_{i} Y_{j}$, as measured by the product of national income and (b) decreases in bilateral trade and tariff costs $\tau_{i j}$. As regards the effect of public export insurance schemes, Eq. 4 gives rise to the further hypotheses that (c) modest payment risks $\lambda$ (reflecting political and commercial stability on foreign markets) and (d) issuing state-guaranteed export insurance at subsidised rates $s(r, \bar{\gamma})$ (e.g. premiums and recoveries are inadequate to cover prospective claims) tend to promote exports between $i$ and $j$. Recall, however, from the discussion on Eq. 1 that such an impact rests on the assumption that insurance markets are incomplete. Otherwise, financial markets or the private insurance industry would already absorb payment risks to such and extent that additional securities would not affect a firms' desire to engage in international trade. Against the background of the present gravity equation, the following section endeavours to confront the resulting hypotheses with the data.

\section{Export credit insurance in OECD countries}

This section presents the methodology and results of what is to our knowledge the first comprehensive study on the extent to which export credit agencies (ECAs) supported by OECD member countries achieve their stated objective of promoting trade in favour of national industries. Thereby, Eq. 4 encapsulates the ways in which public insurance schemes might give rise to exports in excess of exchanges reflecting countries' economic size as well as natural and artificial trade barriers.

Data have been collected from several sources for the years between 1999 and 2005. In particular, export values at which the 30 OECD members trade

\footnotetext{
${ }^{6}$ See Baltensperger and Herger (2007) for detailed discussion. 
with other countries around the world were extracted from the IMF Direction of Trade Statistics (DOTS). ${ }^{7}$

The enactment of the Knaepen Package in 1997 has led the OECD to publish annual statistics on "Export Credit Activities" reporting to what extent collected premiums, disbursed claims, and retrieved recoveries contributed to annual cash flows, as well as the volume of newly insured export credit broken down according to reporting and recipient country. Based on that, Dewit (2001, pp. 577-580) proposes to employ disbursed claims as a fraction of collected premiums and recoveries as a suitable proxy for public export insurance subsidisation, that is $s(r, \rho) \approx$ claims/(premiums + recoveries). ${ }^{8}$ Furthermore, using a scale from 1 to 7 , the OECD releases a regularly updated classification of the default risk inferred to accrue to international trade. For the year 2005, Table 4 of the Appendix lists countries according to their scores. On this basis, member states have agreed on a formula to militate against competing ECAs charging premium rates that are "inadequate to cover the long-term operating costs and losses" (Knaepen Package, Art. 22) and thus initiate premium rate convergence. Coverage ceilings, e.g. the maximal proportion of defaulted exports subject to indemnification, are surveyed in the OECD's "Export Credit Financing Systems in OECD Member Countries and NonMember Countries". However, on markets suffering from aggravated levels of economic and political uncertainty, the percentage loss ordinarily disbursable may be subject to additional terms and conditions. In particular, export insurance to countries scoring a 7 on the OECD's default risk assessment is frequently only available against additional collateral or even completely put off-cover.

Table 5 of the Appendix summarises public insurance policy and trade variables across OECD member countries.

For the 1999 to 2005 period, ECAs within the OECD reported a total of almost 100 billion US\$ worth of newly underwritten business which accounted for about $3 \%$ of worldwide-private and public - export insurance activity as reported to the Berne Union. ${ }^{9}$ As regards percentages of exports covered in individual countries, Korea $(0.93 \%)$, Japan $(0.58 \%)$, Canada $(0.54 \%)$, and France $(0.33 \%)$ granted the highest levels of support to domestic industries. By contrast, Iceland and Ireland do not maintain public export insurance schemes and New Zealand's Export Credit Office (ECO) has reported no medium and

\footnotetext{
${ }^{7}$ Gravity equations typically draw on more comprehensive bilateral trade flows (see e.g. Baldwin and Taglioni 2006). However, the present study looks into the extent to which ECAs impact upon domestic exports wherefore the policy target of unilateral trade flows will serve as dependent variable.

${ }^{8}$ To measure subsidies rather profits on insurance policies, the original measure proposed by Dewit (2001) has been reversed. Alternatively, premiums could be related to the volume of newly underwritten business to proxy for average export insurance conditions. This leaves the amount of disbursed claims and retrieved recoveries unaccounted for. Nevertheless, the undermentioned results are by and large not sensitive to employing alternative proxies for the level of premium subsidies.

${ }^{9}$ This figure has been calculated for the 1999 to 2004 period as figures for 2005 are not available from the latest edition of the Yearbook of the Berne Union.
} 
long-term (e.g. more than one year) exposures during its first years in business. As regards the percentage of received medium and long-term export insurance relative to the grand total of policies issued by OECD countries, the largest recipient countries were mainly emerging markets such as China (8\%), Iran $(5 \%)$, Mexico (5\%), Turkey (5\%), Brazil (3.5\%), Russia (2.5\%), and India (2\%) but also included the United States (10\%). In contrast to the 1980s and the beginning of the 1990s, when many public export insurance schemes suffered from structural deficits (see Dewit 2001, pp. 377-380), on aggregate, premiums and recoveries sufficed to cover claims that were issued during the 1999 to 2005 period by OECD countries.

\subsection{Econometric specification}

Measuring the empirical impact public export insurance schemes exhibit upon the value of exports $(X)$ necessitates transforming the gravity Eq. 4 into an econometric model

$$
\begin{array}{cl}
\ln \left(X_{i j, t}\right)=\beta_{1} \ln \left(Y_{i, t} Y_{j, t}\right)+\beta_{2} \ln \left(\tau_{i j, t}\right) & \text { controls } \\
+\beta_{3} \ln \left(\lambda_{j, t}\right)+\beta_{4} \ln \left(\bar{\gamma}_{i, t}\right)+\beta_{5} \ln s(r, \rho) & \text { export insurance } \\
+\alpha_{i j}+\alpha_{t}+\epsilon_{i j, t} & \text { unobserved effects }
\end{array}
$$

where $i j$ and $t$ index for panel observations across pairs of exporting and importing countries and years between 1999 and 2005, respectively. Logarithmic transformations (ln) mitigate against heteroscedasticity and convert estimated coefficients into elasticities whose magnitudes lend themselves to direct comparison.

The panel data of Eq. 5 can be grouped into control and export insurance variables. Thereby, covariates appearing as capital letters will be employed for estimation in the next section. A synoptic overview of their sources and definitions is relegated to the Appendix.

Control variables include ECONOMIC SIZE as measured by joint gross domestic product, e.g. $Y_{i, t} Y_{j, t}$, which is expected to produce a positive entry as larger markets tend to support more trade. Average bilateral TARIFF rates impose artificial trade costs $(\tau)$ giving rise to an anticipated negative relationship with exports. Exports to just under one fifth of countries are not subject to any tariff barrier, which partly reflects the recent surge in bilateral and multilateral agreements granting preferential market access. In common with most gravity equations, bilateral DISTANCE between capital cities, nominal variables designating countries with a common LANGUAGE or BORDER, as well as whether or not countries are LANDLOCKED account for some of the natural trade frictions. Note that such geographic attributes are time-invariant.

The second line of Eq. 5 contains export insurance variables. These include the payment RISK $(\lambda)$ accruing on foreign markets as proxied by the aforementioned OECD classification, the maximal percentage COVERAGE 
$(\bar{\gamma})$ insurable by state-supported schemes, as well as $\operatorname{SUBSIDIES}(s(r, \rho))$ as defined during the outset of this section.

Econometric pitfalls to estimate Eq. 5 are twofold. Firstly, for country-pairs with particularly small markets and high trade costs, the corner solution of zero-valued exports may prevail, which calls for Tobit estimates. ${ }^{10}$ Secondly, to account for unobserved components, the final line of Eq. 5 introduces a vector of time dummy variables, $\alpha_{t}$, country-pair specific effects, $\alpha_{i j}$, and an idiosyncratic error term, $\epsilon_{i j, t}$. In particular, $\alpha_{t}$ shifts intercepts according to years to offset global trends in inflation. ${ }^{11}$ In case country-pair specific effects $\alpha_{i j}$ are exogenous, they can be modeled as random effects. Otherwise, fixed effects permit to proxy for what Anderson and Wincoop (2003) label multilateral trade resistance e.g. trade frictions such as red-tape, incomplete information, cultural differences, or bureaucratic delays, which do not lend themselves to direct observation.

\subsection{Baseline results}

Columns 1 and 2 of Table 1 report random effects estimates from regressing ECONOMIC SIZE, trade cost, and export insurance variables of Section 2.1 on to the value of exported goods and services across more than 4,000 country-pairs with in excess of 14,000 observations. The first column employs linear least squares as the estimation technique. Meanwhile, column 2 employs a random effects Tobit framework (hereafter 'RET') to better account for the 400 observations from 99 country-pairs that did not attract exports from OECD members during at least one of the years between 1999 and 2005 . Here, covariates are supposed to control for relevant trade variables to such an extent that the unobserved country-pair effects $\alpha_{i j}$ merely introduce an additional source of randomness. By means of an array of fixed effects $\alpha_{i j}$, columns 3 and 4 account for the heterogeneity across country-pairs in a more robust manner absorbing time-constant variables such as DISTANCE, LANGUAGE, LANDLOCK, or BORDER. Then again, column 4 adopts fixed effects within a Tobit framework (hereafter 'FET').

Control variables enter all specifications with the expected sign in the sense that trade flows tend to increase with joint market size and decrease in trade costs as measured by low tariffs and geographical and cultural proximity in terms of country-pairs with closely located capital cities, direct access to the sea, or sharing a common language and border.

\footnotetext{
${ }^{10}$ Note that a 1 is added to export values to avoid zero-valued observations from dropping out when applying a logarithmic transformation.

${ }^{11}$ Alternatively, nominal variables might be deflated by means of price indices. The caveat against this lies in the excessive amount of information needed to correctly adjust for price changes accruing to trade and income variables as inherent in the variables $P_{j}$ and $\Omega_{j}$ of Eq. 4. Indeed, most countries do not publish separate price indices for traded goods and services (Baldwin and Taglioni 2006).
} 
Table 1 Exports and export insurance

\begin{tabular}{|c|c|c|c|c|}
\hline \multirow{2}{*}{$\begin{array}{l}\text { Panel techniques } \\
\text { estimation method }\end{array}$} & \multicolumn{2}{|c|}{ Random effects } & \multicolumn{2}{|l|}{ Fixed effects } \\
\hline & $\begin{array}{l}\text { Linear least } \\
\text { squares } \\
\text { (1) }\end{array}$ & $\begin{array}{l}\text { Tobit } \\
\text { (RET) } \\
(2)\end{array}$ & $\begin{array}{l}\text { Linear least } \\
\text { squares } \\
\text { (3) }\end{array}$ & $\begin{array}{l}\text { Tobit } \\
\text { (FET) } \\
(4)\end{array}$ \\
\hline$\overline{\text { Econ. size }\left(Y_{i, t} Y_{j, t}\right)}$ & $\begin{array}{l}0.708 * * * \\
(0.005)\end{array}$ & $\begin{array}{l}0.713 * * * \\
(0.002)\end{array}$ & $\begin{array}{l}0.358 * * * \\
(0.028)\end{array}$ & $\begin{array}{l}0.283 * * * \\
(0.017)\end{array}$ \\
\hline Distance & $\begin{array}{l}-0.142 * * * \\
(0.002)\end{array}$ & $\begin{array}{l}-0.153^{* * *} \\
(0.001)\end{array}$ & & \\
\hline Language & $\begin{array}{l}0.584 * * * \\
(0.032)\end{array}$ & $\begin{array}{l}0.414 * * * \\
(0.016)\end{array}$ & & \\
\hline Landlock & $\begin{array}{l}-0.474 * * * \\
(0.020)\end{array}$ & $\begin{array}{l}-0.442 * * * \\
(0.011)\end{array}$ & & \\
\hline Border & $\begin{array}{l}1.322 * * * \\
(0.057)\end{array}$ & $\begin{array}{l}1.960 * * * \\
(0.030)\end{array}$ & & \\
\hline Tariff & $\begin{array}{l}-0.162 * * * \\
(0.011)\end{array}$ & $\begin{array}{l}-0.057^{* * *} \\
(0.006)\end{array}$ & $\begin{array}{l}-0.037 * * * \\
(0.012)\end{array}$ & $\begin{array}{l}-0.017 \\
(0.011)\end{array}$ \\
\hline $\operatorname{Risk}\left(\lambda_{j, t}\right)$ & $\begin{array}{l}-0.487 * * * \\
(0.019)\end{array}$ & $\begin{array}{l}-0.525^{* * *} \\
(0.010)\end{array}$ & $\begin{array}{l}-0.311 * * * \\
(0.047)\end{array}$ & $\begin{array}{l}-0.258^{* * * *} \\
(0.042)\end{array}$ \\
\hline Coverage $\left(\bar{\gamma}_{j, t}\right)$ & $\begin{array}{l}0.042 * * * \\
(0.010)\end{array}$ & $\begin{array}{l}0.029 * * * \\
(0.004)\end{array}$ & $\begin{array}{l}0.010 \\
(0.011)\end{array}$ & $\begin{array}{l}0.015 \\
(0.009)\end{array}$ \\
\hline Subsidy $(s(r, \rho))$ & $\begin{array}{l}0.001 \\
(0.008)\end{array}$ & $\begin{array}{l}0.085 * * * \\
(0.004)\end{array}$ & $\begin{array}{l}0.016^{* * *} \\
(0.007)\end{array}$ & $\begin{array}{l}0.025 * * * \\
(0.006)\end{array}$ \\
\hline Intercept & $\begin{array}{l}-10.65^{* * * *} \\
(0.193)\end{array}$ & $\begin{array}{l}-10.57 * * * \\
(0.061)\end{array}$ & & \\
\hline$N$ & 14,501 & 14,501 & 14,663 & 14,663 \\
\hline Country-pairs & 4,130 & 4,130 & 4,159 & 4,159 \\
\hline $\begin{array}{l}\text { Log likelihood } \\
R^{2}\end{array}$ & 0.851 & $-14,171$ & 0.983 & $-7,305$ \\
\hline
\end{tabular}

The dependent variable is the value of EXPORTS. All specification contain country-pair $\left(\alpha_{i j}\right)$ and time-specific effects $\left(\alpha_{t}\right)$. Robust standard errors are given in parentheses.

*Coefficients are significant at the $10 \%$ level

**Significant at the $5 \%$ level

***Significant at the $1 \%$ level

Export insurance variables in the form of COVERAGE ceilings and inferred premium SUBSIDIES reveal in how far more generous public insurance schemes offset payment RISKS and therefore induce firms to ship more goods to risky markets. The statistically significant entry of RISK suggests that exporters are reluctant to ship goods towards markets with a notoriously patchy credit history in spite of export insurance to hedge against defaulted payments. The threat of opportunistic foreign buyers refusing to pay for consigned commodities may well undermine a firm's willingness to assume a trade credit. According to North (1990), economic exchanges conducted at arm's length rest indeed on carefully balancing the establishment of a robust political and legal mandate to safeguard contractual obligations against the threat of authorities abusing the surrendered public power for private benefit. Aggravated uncertainties inherent in international trade are likely to reinforce the role of an efficient and reliable institutional design, which exporters can fall back on if confronted with default. 
According to the positive entries of COVERAGE and SUBSIDIES of Table 1, issuing export credits with more generous state-guarantees tends to promote trade. However, when introducing fixed effects, COVERAGE fails to produce significance. Furthermore, compared with the impact of payment RISKS, the magnitude of coefficient elasticities of export insurance variables appears to be rather modest. Indeed, even with the comparatively large estimates of column 2 of Table 1, simulations predict that exports within the current sample would have increased by a mere $2 \%$ would all OECD countries have adopted self-funded insurance schemes that fully cover defaulted payments. Of note, such "trade creation" would involve substantial commercial risk that appears neither to be marketable nor politically supportable at current conditions. By way of contrast, were payment frictions in all countries to be reduced to a level consistent with a score of 1 for RISK, across the current sample, exports are predicted to increase by $15 \%$.

Though random effects allow exploiting cross-country variation, which provides the primary source of heterogeneity when analysing trade flows, it is also prone to omitting unobserved variables and lead to biased statistical inference (Baldwin and Taglioni 2006). Fixed effects yield, within the current sample, substantially smaller estimates. Indeed, the difference between coefficients of columns 1 and 3 or columns 2 and 4 provides the basis for conducting a Hausman-test, which, with test statistics $\chi^{2}$ of, respectively, 83.87 and 1,556 rejects the hypothesis of consistent random effects estimates at any conventional level. Owing to their robustness, the remainder will therefore assess the extent to which ECAs promote exports within a FET framework. Of note, employing alternative methods would not have reversed the sign of any entry, but primarily affected the inference on coefficient's significance. For the sake of brevity, these results are not reported here.

\subsection{Further results and robustness checks}

To offset the vast differences in the proliferation of secure payments across countries, ${ }^{12}$ ECAs typically adjust their insurance policies according to the degree of risk involved. According to Abraham and Dewit (2000), this manifests primarily in reduced coverage and higher premium rates when countries witness aggravated levels of default risk due to e.g. high levels of external debt, insufficient foreign currency reserves, low rates of economic growth, or modest financial inflows in terms of foreign direct investment. To account for the more basic export insurance on foreign markets where payments are less likely to occur on a contractual basis, the first column of Table 2 interacts export insurance SUBSIDIES and COVERAGE with the inverse of RISK. The results lend further support to the abovementioned finding that public export insurance schemes fail to offset the default risk and only modestly promote exports.

\footnotetext{
${ }^{12}$ For a discussion on the origin of the vast differences in creditor protection around the world see e.g. La Porta et al. (1997) or Acemoglu and Johnson (2005).
} 
Table 2 Exports and Export Insurance according to Sub-samples

\begin{tabular}{|c|c|c|c|c|c|c|}
\hline \multirow[t]{2}{*}{ Sample } & \multirow{2}{*}{$\begin{array}{l}\text { Risk adj. } \\
\text { insurance } \\
\text { (2) }\end{array}$} & \multirow{2}{*}{$\begin{array}{l}\text { Without } \\
\text { risk } 7 \\
\text { (2) }\end{array}$} & \multicolumn{3}{|c|}{ Income group } & \multirow{2}{*}{$\begin{array}{l}\text { Former } \\
\text { colonies } \\
(6)\end{array}$} \\
\hline & & & $\begin{array}{l}\text { High } \\
(3)\end{array}$ & $\begin{array}{l}\text { Middle } \\
(4)\end{array}$ & $\begin{array}{l}\text { Low } \\
(5)\end{array}$ & \\
\hline Econ. Size $\left(Y_{i, t} Y_{j, t}\right)$ & $\begin{array}{l}0.282 * * * \\
(0.017)\end{array}$ & $\begin{array}{l}0.415 * * * \\
(0.017)\end{array}$ & $\begin{array}{l}0.335 * * * \\
(0.036)\end{array}$ & $\begin{array}{l}0.410 * * * \\
(0.020)\end{array}$ & $\begin{array}{l}0.076 * \\
(0.041)\end{array}$ & $\begin{array}{l}0.182 * \\
(0.099)\end{array}$ \\
\hline Tariff & $\begin{array}{l}-0.017 * \\
(0.011)\end{array}$ & $\begin{array}{l}0.014 \\
(0.011)\end{array}$ & $\begin{array}{l}-0.089 * * \\
(0.034)\end{array}$ & $\begin{array}{l}-0.027 * * \\
(0.013)\end{array}$ & $\begin{array}{l}-0.208 * * * \\
(0.043)\end{array}$ & $\begin{array}{l}-0.035 \\
(0.065)\end{array}$ \\
\hline $\operatorname{Risk}\left(\lambda_{j, t}\right)$ & $\begin{array}{l}-0.226 * * * \\
(0.043)\end{array}$ & $\begin{array}{l}-0.071 \\
(0.044)\end{array}$ & $\begin{array}{l}0.647 * * * \\
(0.119)\end{array}$ & $\begin{array}{l}-0.268 * * * \\
(0.052)\end{array}$ & $\begin{array}{l}-1.046 * * * \\
(0.191)\end{array}$ & $\begin{array}{l}-0.457 * * \\
(0.203)\end{array}$ \\
\hline Coverage $\left(\bar{\gamma}_{j, t}\right)$ & $\begin{array}{l}0.016 * \\
(0.009)\end{array}$ & $\begin{array}{l}0.011 \\
(0.010)\end{array}$ & $\begin{array}{l}0.016 \\
(0.013)\end{array}$ & $\begin{array}{l}0.006 \\
(0.013)\end{array}$ & $\begin{array}{l}0.028 \\
(0.025)\end{array}$ & $\begin{array}{l}14.52 * * \\
(5.826)\end{array}$ \\
\hline Subsidy $(s(r, \rho))$ & $\begin{array}{l}0.025 * \\
(0.006)\end{array}$ & $\begin{array}{l}0.020 * * * \\
(0.006)\end{array}$ & $\begin{array}{l}0.033 * * * \\
(0.010)\end{array}$ & $\begin{array}{l}0.018 * * \\
(0.009)\end{array}$ & $\begin{array}{l}0.017 \\
(0.013)\end{array}$ & $\begin{array}{l}-0.060 * \\
(0.034)\end{array}$ \\
\hline$N$ & 14,663 & 10,691 & 4,364 & 6,799 & 3,500 & 352 \\
\hline Country-pairs & 4,159 & 2,876 & 2,026 & 2,262 & 1,169 & 115 \\
\hline Log likelihood & $-7,304$ & $-5,004$ & $-1,952$ & $-3,466$ & $-1,391$ & -40.95 \\
\hline
\end{tabular}

The dependent variable is the value of EXPORTS. All variables are expressed in logarithms. Estimation is made by fixed effects Tobit (FET). Robust standard errors are given in parentheses

*Coefficients are significant at the $10 \%$ level

**Significant at the $5 \%$ level

***Significant at the $1 \%$ level

Even ECAs issued with a state-guarantee tend to put extremely risky markets, which are e.g. experiencing political unrest or financial crisis, at least temporarily off-cover. Column 2 of Table 2 controls for this by dropping countries scoring a 7 on the OECD's assessment of the prospect of insecure payments. Then, RISK no longer produces a significant entry suggesting that the various modes of export insurance as well as financial instruments suffice to hedge against the menace of default, unless pervasive levels of commercial and political instability are involved. Again, the impact of more generous export insurance schemes remains moderate.

As noted at the outset of Section 2, publicly supported export insurers tend to target their activities to emerging markets rather than to the financially and economically least developed countries. Against this background, columns 3 to 5 of Table 2 divide the sample into low, middle, and high-income countries according to the classification of the World Bank (see Table 4 of the Appendix). This does not overturn the aforementioned finding that public export insurance schemes are, by and large, ineffective in offsetting the impact of payment risk upon trade flows. ${ }^{13}$ To a modest degree, OECD countries

\footnotetext{
${ }^{13}$ In high-income countries, RISK enters with a positive sign. Countries scoring a default risk higher than 2 despite having relatively high incomes include Bahrain, Cyprus, Israel, Qatar, and Saudi Arabia. Potentially, in oil-rich countries and countries located in areas with a history of armed conflict, some of the trade-off between exporting and payment risks remains opaque. Indeed, excluding these countries yields a negative and significant sign on RISK. Likewise, employing the RET framework suggests that exports across high income countries tend to decrease in the probability of default.
} 
appear to have offered export insurance that expanded trade with high and middle-income countries. By contrast, public export insurance policies seem not to have opened up low-income countries for higher volumes of trade. Possibly, ECAs face fiercer private competition on higher income markets which forces them to offer more comprehensive policies. Across all groups, coverage ceilings restricting the indemnification of export credits fail to promote exports in a statistically significant manner.

Finally, Abraham and Dewit (2000) find that during the 1990s the Belgian OND granted export insurance at subsidised rates primarily to former colonies. Though comprising a mere 115 country-pairs with 352 observations, the final column of Table 2 supports this observation with particularly large impacts arising from the provision of more generous coverage ceilings. Following the theoretical consideration by Dewit (2001), assuming more risk on behalf of the exporting firm seems indeed to provide a potential loophole for ECAs wishing to distribute subsidies without infringing international regulations that prohibit charging inadequately low premium rates. ${ }^{14}$

\section{Summary and conclusion}

For OECD countries and the 1999 to 2005 period, gravity equations uncover the following principal patterns between exports and public export insurance parameters such as default risks, coverage ceilings (e.g. the maximal proportion of trade credit subject to indemnification), and premium subsidies (inferred from the extent to which premium revenues and recoveries cover disbursed claims):

- Publicly supported export insurance schemes absorb at most some of the hazards that risky payments introduce to trade. Insecure payments continue to impede trade primarily in countries with pervasive political and commercial instability.

- To a modest degree, ECAs seem to have extended trade with high and middle-income countries. Conversely, for trade with low-income countries, public insurance schemes appear to have been irrelevant.

- The view that export insurance programs, such as those run by OECD countries, are employed to promote trade with former colonies finds further support. Ostensibly, some trade credits between countries with a shared colonial history received rather comprehensive coverage relative to the default risks involved.

\footnotetext{
${ }^{14}$ The results of this and the previous paragraph are by and large robust towards interacting insurance policy variables with default RISK in order to reflect the more comprehensive protection typically offered when trade is directed towards affluent countries.
} 
- In general, subsidy rates rather than coverage ceilings seem to have provided the policy parameter through which exports have been promoted.

The reluctance of private banks and insurance companies to cover some of the commercial and most of the political risk in financially underdeveloped markets serves as rationale for issuing trade credits with a state-guarantee. Owing, among else, to their commercial and political instability, it has been primarily the low-income countries, which have hitherto not benefited fully from the recent growth in global trade. In case incomplete insurance markets offer only limited possibilities to hedge against the risk of non-payment, public insurance schemes are, thus, supposed to promote trade and open up risky markets to trade.

Against that, the judgment on public export insurance schemes must be mixed. Though such schemes appear to have promoted trade towards middle and high-income countries, they failed to facilitate trade with low-income, and thus rather unstable, countries. Further caveats apply. It remains particularly unclear, whether or not this rather modest level of export promotion provides a sufficient reason for exposing public finance to what is essentially a risk accruing to a small fraction of exporting firms. As with any insurance scheme, issuing trade credits with a state-guarantee may furthermore give rise to adverse incentives, e.g. when exporting firms engage in excessive risk taking.

For countries wishing to support their export industry, the benefits of public export insurances schemes should therefore not be overestimated nor their caveats be underestimated. Plainly, public export insurance schemes permit countries to circumvent, but not to even out, payment frictions. However, countries typically owe their patchy credit histories to a combination of dysfunctional legal institutions, poor macroeconomic policies, and political instability. Rather than maintaining a public ownership stake in an ECA, this suggests that international trade could benefit in a more sustainable way from efforts that directly work against the various sources underlying payment risks.

Acknowledgements This paper has benefited from valuable comments and suggestions by seminar participants at the WTI in Berne, Susan Kaplan, and a thoughtful referee. Financial support of the Ecoscientia and the Swiss National Science Foundation is acknowledged with thanks. The usual disclaimer applies. 


\section{Data Appendix}

Tables 3, 4, 5

Table 3 Description of the data set

\begin{tabular}{|c|c|c|}
\hline Variable & Description & Source \\
\hline Exports & $\begin{array}{l}\text { Exports in logarithmic US\$ million. Original } \\
\text { values have been added with } 1 \text { to allow for } \\
\text { logarithmic transformations on zero-valued } \\
\text { export activities }\end{array}$ & $\begin{array}{l}\text { Direction of Trade } \\
\text { Statistics, IMF }\end{array}$ \\
\hline $\begin{array}{l}\text { Economic } \\
\text { Size }\end{array}$ & $\begin{array}{l}\text { Joint gross domestic product (GDP) across } \\
\text { country-pairs in logarithmic US\$ million }\end{array}$ & $\begin{array}{l}\text { World Development } \\
\text { Indicators (WDI), } \\
\text { World Bank }\end{array}$ \\
\hline Tariff & $\begin{array}{l}\text { Average tariff rate levied upon and weighted } \\
\text { according to the value of imports. In cases } \\
\text { where countries have entered a Free Trade } \\
\text { Agreement or Customs Union, tariffs equal } 0\end{array}$ & $\begin{array}{l}\text { TRAINS database, } \\
\text { World Bank and World } \\
\text { Trade Organisation }\end{array}$ \\
\hline Distance & $\begin{array}{l}\text { Great-circle distance between capital cities } \\
\text { in terms of (logarithmic) kilometres }\end{array}$ & Compiled \\
\hline Language & Nominal variable for a common official language & $\begin{array}{l}\text { Compiled from } \\
\text { "CIA World Factbook" }\end{array}$ \\
\hline Landlock & $\begin{array}{l}\text { Variable indicating for country-pairs that } 0= \\
\text { neither of them is landlocked, } 1=\text { one of them } \\
\text { is landlocked, } 2=\text { both of them are landlocked }\end{array}$ & $\begin{array}{l}\text { Compiled from" } \\
\text { "CIA World Factbook" }\end{array}$ \\
\hline Border & Nominal variable for a common border & $\begin{array}{l}\text { Compiled from } \\
\text { "CIA World Factbook" }\end{array}$ \\
\hline Risk & $\begin{array}{l}\text { Assessment of the risk of default on international } \\
\text { payments on a scale from } 1 \text { to } 7 \text { with higher } \\
\text { values designating higher risk }\end{array}$ & Compiled from OECD \\
\hline Coverage & $\begin{array}{l}\text { Coverage ceiling designating the maximal insur- } \\
\text { ance coverage against default due to political } \\
\text { risks an exporter can take out from public } \\
\text { export insurance. To allow for a logarithmic } \\
\text { transformation in countries without public ex- } \\
\text { port insurance, original values are added with } 1\end{array}$ & $\begin{array}{l}\text { Compiled from OECD } \\
\text { "Export Credit Financing } \\
\text { Systems in OECD } \\
\text { Member Countries and } \\
\text { Non-Member Countries" }\end{array}$ \\
\hline Subsidy & $\begin{array}{l}\text { Measure of export insurance subsidies in terms } \\
\text { of the amount of funds ECAs disperse in claims } \\
\text { as a fraction of collected premiums and } \\
\text { retrieved recoveries, that is claims/(premiums+ } \\
\text { recoveries). To allow for a logarithmic } \\
\text { transformation in countries without public } \\
\text { export insurance, claims are added with } 1\end{array}$ & $\begin{array}{l}\text { Compiled from OECD } \\
\text { "Export Credit Activities" }\end{array}$ \\
\hline
\end{tabular}




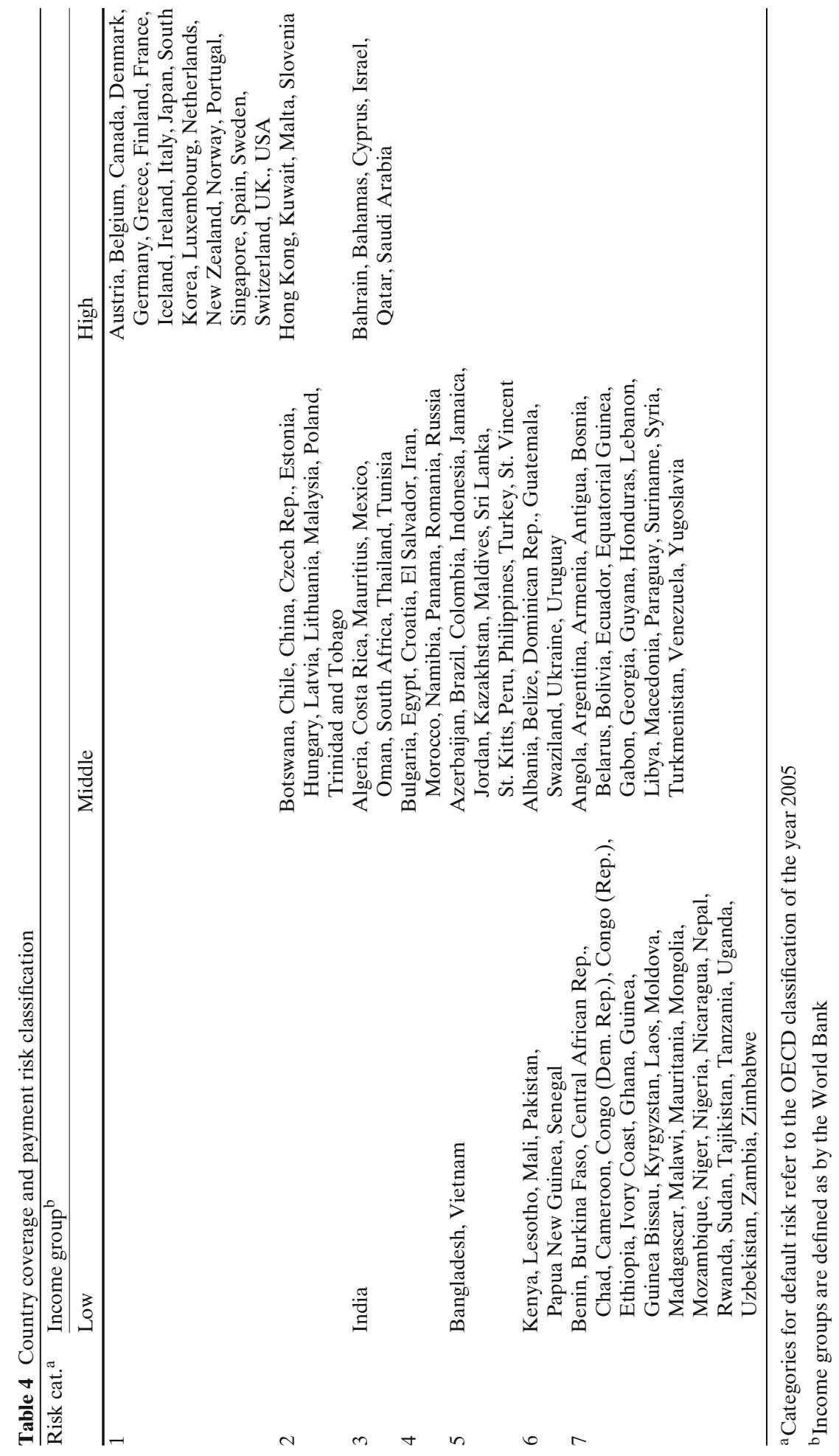




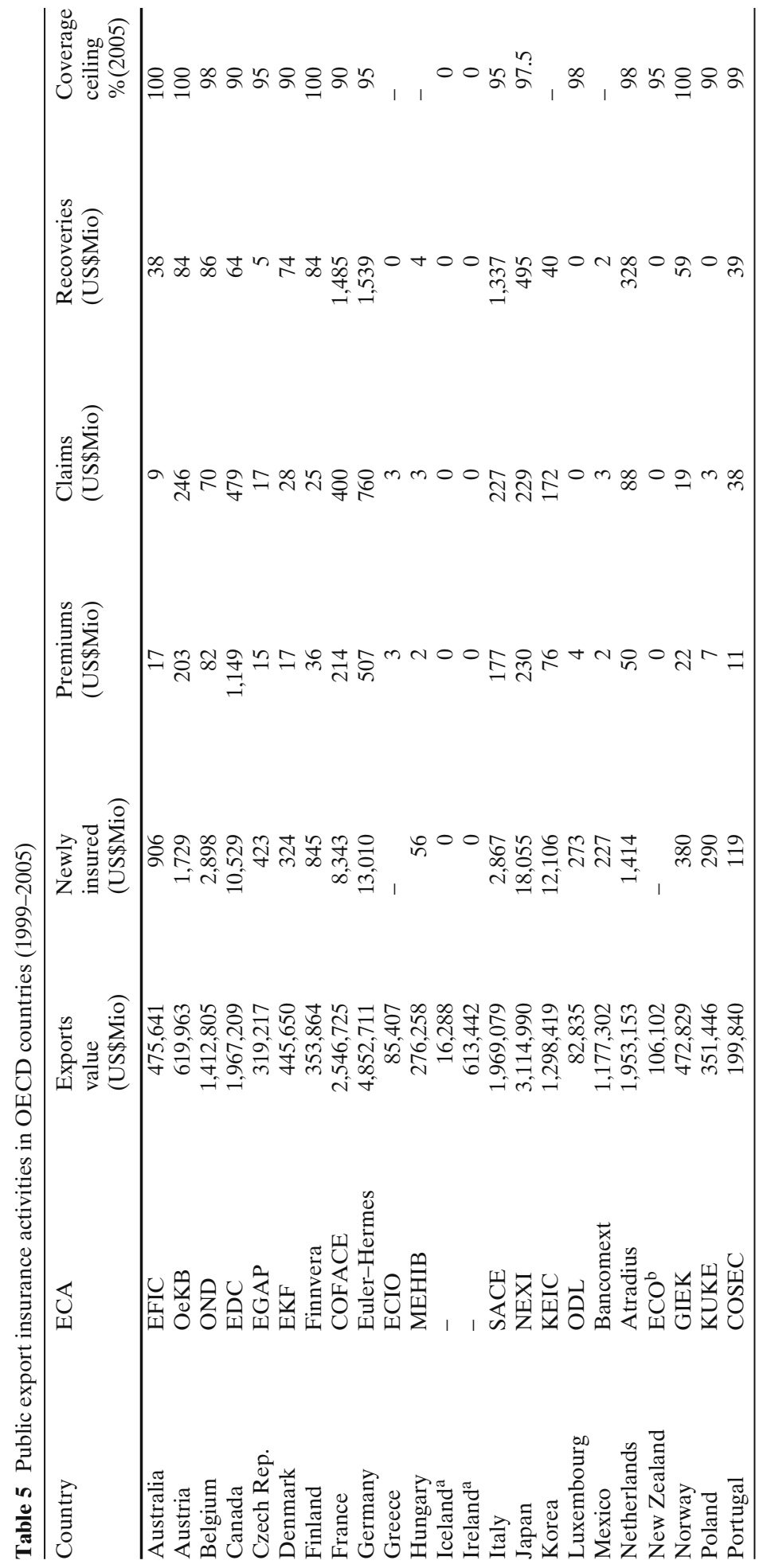




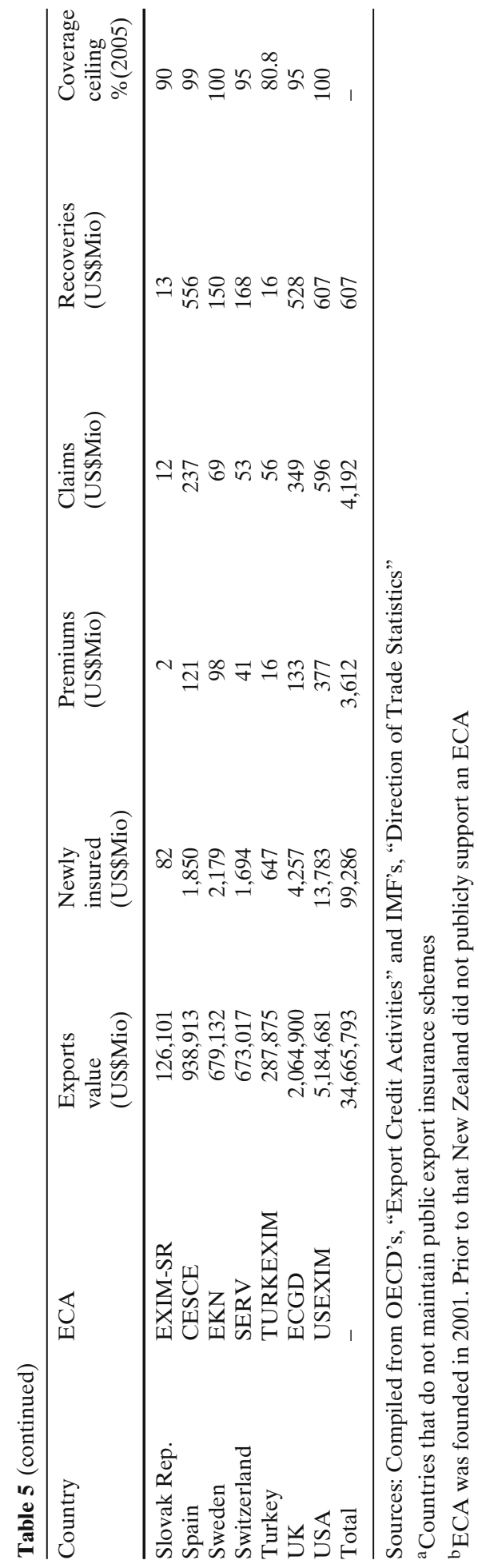




\section{References}

Abraham F, Dewit G (2000) Export promotion via official export insurance. Open Econ Rev 11:5-26

Acemoglu D, Johnson S (2005) Unbundling institutions. J Polit Econ 113:949-995

Alsem K, Antufjew J, Huizingh E, Koning R, Sterken E, Woltil M (2003) Insurability of export credit risks. SOM Research Report 03F07. Groningen

Anderson JE, Wincoop EV (2003) Gravity with gravitas: a solution to the border puzzle. The Amer Econ Rev 93:170-192

Baldwin R, Taglioni D (2006) Gravity for dummies and dummies for gravity equations. NBER Working Paper 12516, Cambridge, MA

Baltensperger E, Herger N (2007) Exporting against risk? Theory and evidence from public export insurance schemes in OECD countries. NCCR Working Paper No 2007/29

Berne Union (2006) Yearbook 2006. London

Boote AR, Ross DC (1998) Officially supported export credits: recent developments and prospects. World Economic and Financial Surveys. International Monetary Fund, Washington

Carmichael C (1987) The control of export credit subsidies and its welfare consequences. J Int Econ 23:1-19

Dewit G (2001) Intervention in risky export markets: insurance, strategic action or aid? European J Polit Econ 17:575-592

Dewit G (2002) Risky business: multinationals, uncertainty and asymmetric insurance. Economica 69:357-370

Fingerand MK, Schuknecht L (1999) Trade, finance and financial crisis. WTO Special Studies 3. World Trade Organisation, Geneva

Henry DP (1987) The financial cost of export credit guarantee programs. Rand Publication Series, Santa Monica

La Porta R, Lopez-De-Silanes F, Shleifer A, Vishny RW (1997) Legal determinants of external finance. The J Finance 52:1131-1150

North D (1990) Institutions, institutional change, and economic performance. Cambridge Univ. Press, Cambridge

OECD (various years) Export Credit Activities. Paris

OECD (various years) Export Credit Financing Systems in OECD Member Countries and NonMember Countries. Paris

Stephens M (1998) Export credit agencies, trade finance and South East Asia. IMF Working Paper 78/175. Washington 